\title{
SERVICES OF OPEN INNOVATION CREATION BY USERS OF CROWDSOURCING PLATFORMS
}

\author{
MAŁGORZATA DOLIŃSKA \\ University of Maria Curie-Skłodowska in Lublin, POLAND \\ e-mail: m.dolinska@umcs.lublin.pl
}

RECEIVED
ACCEPTED
JEL
CLASSIFICATION
KEYWORDS

ABSTRACT
9 August 2017

15 December 2017

031

open innovation, process, crowdsourcing platform, collaborators, services

Innovation becomes a driving force of contemporary companies' competitiveness. Companies evaluate from close innovations towards open and networked innovations. They use innovative potential of their outside partners, consumers within outside networks, also developed on the Internet's crowdsourcing platforms.

The purpose of this paper is to present providing services by the crowdsourcing platform users, that is the crowd members, the managers and the innovative companies during their mutual cooperation in execution of open innovation process activities on the Internet.

The paper also presents examples of services which are offered by users of each analyzed kind during their cooperation in accomplishment of open innovation process activities on existing crowdsourcing platforms in the economic practice.

\section{Introduction}

Evolution from closed to open innovation is connected with development of interorganizational networks and creation new values, knowledge, innovations by collaborators of these networks, also by the Internet's community (the crowd) during execution of open innovation process activities on crowdsourcing platforms. 
The goal of the crowdsourcing platform is to engage active members (co-creators) of the crowd as prosumers (producers and actual or potential consumers) that have both the willingness, capacity and ability in solving problems and creating open innovations also new products for innovative companies. Services of IT-based crowdsourcing are offered by an organization that directly manages solving problems, creating value, and developing open innovations for innovative company(-ies) by the crowd members on the Internet. The manager of the platform participates in mutual interaction, communication with members of the crowd and the innovative company experts, and cooperate with them in collective provision of services in accomplishment of open innovation process activities on crowdsourcing platforms.

The purpose of this paper is to present providing services by the crowdsourcing platform users, that is the crowd members, the managers and the innovative companies during their mutual cooperation in execution of open innovation process activities on the Internet.

The paper determines an idea of open, networked innovation process, characterizes principles of using crowdsourcing and the role of the crowd in creating innovations for innovative companies on the Internet. It determines and describes services which are provided by the crowd members, the managers and the innovative companies during their mutual cooperation in execution of open innovation process activities. Examples of collective providing these services by the analyzed kinds of collaborators are presented for the existing crowdsourcing platforms in the economic practice.

\section{Creation of open innovations on the Internet}

Contemporary companies no longer innovate in isolation but through a complex set of mutual interactions and knowledge based relationships (mutual collaboration) with external partners, suppliers and consumers of knowledge, innovative solutions, and also creative members of open (web-based) innovation platforms (OIPs) networks on the Internet. Innovation network is an organization with flexible structure and its partners are intensively collaborating among themselves during mutual information exchange, knowledge management and learning in open innovation processes (Dolińska, 2015, 2016).

Companies have increasingly shifted from innovation initiatives that are centered on internal resources of knowledge (closed innovation) to those are centered on external networks - said another way, a shift from firmcentric innovation to network-centric and open innovation (Nambisan, Sawhney, 2011, p. 40). Open innovation characterizes organizational framework aimed at purposive inflows of external knowledge and ideas to accelerate internal innovation (in-bound open innovation), and purposive outflows of them to support external innovation (out-bound open innovation), or both that is exchange knowledge, ideas with external collaborators (Malhotra, Majchrzak, 2014, p. 104).

OIPs, also crowdsourcing platforms can be a means for companies to accelerate the open innovation process. In such platforms, stakeholders contribute to and collaborate on designing ideas, propose new concepts and trends, present innovative solutions to win contests and to answer companies' needs (Battistella, Nonino, 2012, p. 558) and also to meet own expectations. The three forms of collaboration and participation in OIPs are: crowsourcing, common-based peer production, and open source software.

The crowdsourcing platform offers IT-enabled services provided by its collaborators in open innovation process activities, in which companies learn new values, innovative solutions (also new products) from the Internet's community. Open source software is developed collaboratively by different and independent, geographically distant 
program developers. Common-based peer production refers to a new model of production performed collaboratively, where a large number of people is coordinated into large project groups without traditional hierarchical organization.

\section{Providing services by collaborators of the crowdsourcing plattorm in open innovation process}

The emergence of the Internet has created new opportunities to capitalize on consumer' creativity and knowledge during innovative solution, new product development by virtual consumers on crowdsourcing platforms, and their cooperation has been recognized as a promising, effective open innovation practice for companies (Füller, Matzler, Hutter, Hautz, 2012, p. 247). Today, members of the crowd on crowdsourcing platforms not only contribute ideas and input to innovation, also new product development, but they share goods, services, space, and money to deliver solutions that traditionally have been performed strictly by the companies themselves (Kohler, 2015, p. 63).

Crowdsourcing-based open innovation model consists of three elements. First, companies building their business upon the crowd need to adopt an open innovation model. Second, opening up innovation processes and knowledge resources to external creators of the Internet's community can make a significantly greater set of resources available to the company and allows it to share social networks, peer-to-peer technologies and mobile connectivity to invite users to participate in value creation activities. Third, by taking part in certain activities, the crowd members co-create value with the platform managers or by interacting with innovative companies. The platform managers facilitate interactions and information, knowledge exchanges along the entire process of open innovation (Zott, Amit, Massa, 2011; Kohler, 2015).

The manager of the crowdsourcing platform may be: 1) the innovative company that is the owner of the platform and cooperate with the crowd, or 2) the agent and the owner of the platform that organizes cooperation between the innovative companies and the crowd, and also collaborate with them during accomplishment of all or certain activities of open innovation process.

The paper tries to answer and discuss the following research question.

Can mutual cooperation of crowdsourcing users on the Internet that is the crowd members, the managers and innovative companies enable them to provide suitable services during accomplishment of open innovation process activities on the crowdsourcing platform.

Open innovation process on crowdsourcing platforms can consists of many activities and each platform and its collaborators serve one or more, or all of these activities. Members of the crowd can participate and cooperate with innovative company and the manager of the platform in providing services during collective execution of the determined and analyzed in this paper activities (that is one activity, a few, or all activities) of open innovation process: 1) presentation of expectations; 2) generation of new ideas; 3) screening design ideas; 4) innovation elaboration, testing; 5) innovation application, development; 6) innovation promotion, sale, diffusion.

Crowdsourcing collaborators on the Internet cooperate among themselves during providing relevant services in activities of the open innovation process which is executed by them collectively on the crowdsourcing platform (see |Table 1).

\section{Services provided by the crowdsourcing platiform collaborators in the economic practice}

Services provided by collaborators in activities of open innovation process activities are presented as descriptive cases for the crowdsourcing platforms: InnoCentive, Mulino Bianco, LEGO Cuusoo and Amazon's Mechanical Turk. 
InnoCentive firm manages the massive problem-solving and innovation-creating crowdsourcing platform. It cooperates with innovative companies and the crowd, organize and manage providing services by them on the platform. Solvers register on the InnoCentive website, read the challenge and within a specific timeframe send back the elaborated solution.

Interactions between solvers regarding a specific challenge are only possible if they formally decide to form a team of the crowd members, collaborate among themselves and share the prize. The open innovation process on this platform consists of activities: 1) a innovative company comes up with a problem for solving and dissects the problem into smaller challenges; 2) scientists across the world (the crowd) generate and submit possible, elaborated by then solutions; 3) InnoCentive evaluates the proposed solutions; 4) the managers of the platform choose the winning solutions, integrates them back as innovative elaboration and the answer to the original problem (Vuculescu, Bergenholtz, 2014).

The Mulino Bianco company produces a wide variety of bakery products. The crowdsourcing platform of this firm is developed on the basis of its virtual communication and collaboration with the Internet's community via the application of innovative marketing techniques. The Mulino Bianco crowdsourcing platform cooperates with own consumers and enables the community of them to propose new product ideas, vote for the most original ones.

Table 1. Providing services by the crowdsourcing platform collaborators in open innovation process activities

\begin{tabular}{|c|c|c|}
\hline \multirow{2}{*}{$\begin{array}{l}\text { Open innovation } \\
\text { process activities }\end{array}$} & \multicolumn{2}{|c|}{ Services provided by collaborators on the crowdsourcing platform } \\
\hline & the crowd members & the manager and the innovative company \\
\hline $\begin{array}{l}\text { Presentation of } \\
\text { expectations }\end{array}$ & $\begin{array}{l}\text { Presenting new values, needs, expectations of customers; } \\
\text { anticipating changes on determined markets. }\end{array}$ & $\begin{array}{l}\text { Determining problems for solving, innovations for designing; } \\
\text { engaging the crowd in anticipating evolution of markets. }\end{array}$ \\
\hline Generation of new idea & $\begin{array}{l}\text { Using creativity, experiences, knowledge by the crowd, } \\
\text { generation of new design ideas, submitting them online. }\end{array}$ & $\begin{array}{l}\text { Organizing contests for proposed by the crowd new design } \\
\text { ideas; exchange, connection of knowledge, experience of the } \\
\text { crowd and the innovative company. }\end{array}$ \\
\hline Scree & $\begin{array}{l}\text { Evaluating the design ideas, voting on them, discussion on } \\
\text { proposed ideas. }\end{array}$ & $\begin{array}{l}\text { Results of the crowd voting are considered as an indication of } \\
\text { buyer interest in design ideas; choosing accurate, profitable } \\
\text { solutions by the manager on the basis of the crowd opinions, } \\
\text { financial and marketing analysis of new solution application } \\
\text { by the company. }\end{array}$ \\
\hline $\begin{array}{l}\text { Innovation elaboration, } \\
\text { testing }\end{array}$ & $\begin{array}{l}\text { Active (co-)creating, developing innovations; testing and } \\
\text { evaluating new solutions using proposed software. }\end{array}$ & $\begin{array}{l}\text { Testing elaborated innovative solutions and connected with } \\
\text { them requirements in collaboration with the crowd. }\end{array}$ \\
\hline $\begin{array}{l}\text { Innovation application, } \\
\text { development }\end{array}$ & $\begin{array}{l}\text { Opinions of the crowd provide a market test of the proposed } \\
\text { solution, which is the best candidate for implementation. }\end{array}$ & $\begin{array}{l}\text { Organizing participation of the crowd in application and/or } \\
\text { development of the best innovative solutions; the company } \\
\text { pays members of the crowd for profitable solutions. }\end{array}$ \\
\hline $\begin{array}{l}\text { Innovation promotion, } \\
\text { sale, diffusion }\end{array}$ & $\begin{array}{l}\text { Promotion of the best solution via own community, social } \\
\text { media channels; cooperation in sale, diffusion of innovations } \\
\text { via online, physical channels. }\end{array}$ & $\begin{array}{l}\text { Involving the crowd in online promotion and/or sale of } \\
\text { innovations; motivating members of the crowd for profitable } \\
\text { selling of innovations (also products). }\end{array}$ \\
\hline
\end{tabular}

Source: own elaboration.

The platform is divided into areas connected with providing services during execution of the following open innovation process activities: 1) presentation of expectations by the company and beginning the project of new product design by creative consumers; 2) generating a new product idea; 3 ) screening and commenting proposed ideas by the crowd; 4) elaboration of the blog on new product assessment and its introduction to production by the company. The aim of this platform crowd is to propose, assess, collect ideas, analyze these ideas, and develop them if they are consistent with the company's mission, vision, and values. The company takes into consideration 
any consumer proposal not related with its current offer. All proposed ideas are commented, evaluated by active consumers, and receive their opinions on viability on the market. The ten most voted ideas are submitted to careful analysis for feasibility by the company. If its outcome is positive, Mulino Bianco begins entering the new product into the market (Di Guardo, Castriotta, 2013).

The LEGO is Danish company of bricks and it cooperates with the manager of the Cuusoo crowdsourcing platform in Tokyo. The services provided in activities of open innovation process on the Cuusoo platform for the LEGO company are characterized for crowdsourcing collaborators: a) the crowd; b) the Cuusoo firm as the manager and the owner of the platform and c) the LEGO company (looking for innovative products on this platform). These collaborators of the platform cooperate among themselves during execution of the following activities of open innovation process (Schlagwein, Bjørn-Andersen, 2014; Lego Ideas, 2017):

1) presentation of expectations:

- active members of the crowd on the platform with consumer-fans on social networks present new values, needs of customers, expected changes (also technological) of LEGO products,

- the Cuusoo firm as the platform manager organizes cooperation with the crowd members, monitors the interactions with them and their discussions on proposed new solutions,

- the LEGO company with the Cuusoo firm encourages consumer-fans to elaborating, developing innovative products;

2) new ideas generation activity:

- creative members of the crowd usually individually generate and submit design ideas to the platform,

- the manager of the platform enable members of the crowd to submit LEGO-related ideas and collect user ideas which might be developed into new LEGO products,

- the LEGO experts determine which submitted ideas are the best candidates for implementation;

3) screening design idea:

- the submitted design ideas to the platform are screened by the crowd members,

- the manager proposes the crowd various options of evaluating, commenting, and voting on submitted design ideas on the platform,

- the LEGO experts evaluate the presented design ideas on the base of votes, qualitative discussion of the crowd members and own opinions;

4) innovation elaboration, testing:

- members of the crowd can use bricks, software or combination of them to prepare designs for potential new LEGO products and they take part in test for the best new product,

- the manager provides voting as a market test before implementation of the new product design,

- highly voted and reviewed by LEGO design idea of best new product will be produced and entered into the market;

5) innovation application, development:

- members of the crowd upload a complete design of accepted new product to the platform,

- uploaded a design of the best new product is transferred by the Cuusoo platform to the LEGO company and is applied by LEGO,

- implementation of accepted new product often is conducted by the LEGO company in cooperation with external firm-partners; 
6) innovation promotion, sale, diffusion:

- the active members of the crowd usually promotes new products via the community of the platform, users' social media channels, and the owner of winning new product idea gets a financial reward (a revenue share on the sales of this product),

- the Cuusoo firm provides communication and collaboration between the LEGO Company and the designer of winning product in its e-marketing,

- the LEGO company lists the new product models in catalogues, involves members of the crowd in e-promotion, selling them via LEGO online and/or physical channels.

Amazon's crowdsourcing - Mechanical Turk (mTurk) is as an "artificial intelligence" web service. It performs "HITs" - human intelligence tasks, that cannot be easily duplicated or replaced by machines. This service applies real persons' intelligence and creative skills in and through the artificial environment of computing networks for solving some problems, proposing and preparing innovative solutions for the Amazon, that are difficult for machines but easy for users of the Internet elaboration (Saxton, Oh, Kishore, 2013, pp. 4-5). The Amazon's community members cooperate with the Amazon's specialists during generation of new design ideas, evaluating them and elaboration of the best innovative solutions for mTurk.

\section{Conclusions}

The conducted in this paper study confirms that mutual cooperation among the crowd members, the manager and the innovative company on the crowdsourcing platform enable them to provide relevant services during accomplishment of open innovation process activities. Future research might solve the problem how to improve relationship management with creative members of the crowd on the crowdsourcing platform because this solution influences on development and efficiency of the platform performance on the Internet.

\section{Referenences}

Battistella, C., Nonino, F. (2012). Open innovation web-based platforms: the impact of different forms of motivation on collaboration. Innovation: Management, Policy \& Practice, 1 (14), 557-575.

Di Guardo, M.C., Castriotta, M. (2013). The challenge and opportunities of crowdsourcing web communities: an Italian case study. International Journal of Electronic Commerce Studies, 1 (4), 79-92.

Dolińska, M. (2016). Otwarte procesy innowacji realizowane w sieci. Ekonomika i Organizacja Przedsiębiorstwa, 6 (797), 77-88.

Dolińska, M. (2015). Knowledge based development of innovative companies within the framework of innovation networks. Innovation: Management, Policy \& Practice, 3 (17), 323-340.

Füller, J., Matzler, K., Hutter, K., Hautz, J. (2012). Consumers' creative talent: Which characteristics quality consumers for open innovation projects? An exploration of asymmetrical effects. Creativity and Innovation Management, 3 (22), 247-261.

Kohler, T. (2015). Crowdsourcing-Based Business Models: How to Create and Capture Value. California Management Review, 4 (57), 63-83.

Lego Ideas: a leading crowdsourcing platform in the Toy Industry (2017). Retrieved from: https://digit.hbs.org/submission/lego-ideas-aleading-crowdsourcing-platform-in-the-toy-industry (10.06.2017).

Malhotra, A., Majchrzak, A. (2014). Managing crowds in innovation challenges. California Management Review, 4 (56), $103-123$.

Nambisan, S., Sawhney, M. (2011). Orchestron processes in network-centric innovation: evidence from the field. Academy of Management Perspectives, August, 40-57.

Saxton, G.D., Oh, O., Kishore, R. (2013). Rules of Crowdsourcing: Models, Issues, and Systems of Control. Information Systems Management, 1 (30), 2-20. 
Schlagwein, D., Bjørn-Andersen, N. (2014). Organizational Learning with Crowdsourcing: The Revelatory Case of LEGO. Journal of the Association for Information Systems, 11 (15), 754-778.

Vuculescu, O., Bergenholtz, C. (2014). How to Solve Problems with Crowds: A Computer-Based Simulation Model. Creativity and Innovation Management, 2 (23), 121-136.

Zott, C., Amit, R., Massa, L. (2011). The business Model: Recent Developments and Future Research. Journal of Management, 4 (37), 1019-1042.

Cite this apticle aS: Dolińska, M. (2018). Services of open innovation creation by users of crowdsourcing platforms. European Journal of Service Management, 2 (26), 45-51. DOI: 10.18276/ejsm.2018.26-06. 